\title{
THE LINKAGE BETWEEN BANK RESTRUCTURING AND BANK DEPOSITS OF COMMERCIAL BANKS OPERATING IN KENYA
}

\author{
Dr. Angela Mucece Kithinji
}

Article DOI: https://doi.org/10.36713/epra4497

\begin{abstract}
Bank restructuring and bank deposits are important concepts to commercial banks because of their role in the financial intermediation. Intervention through financial innovations, increasing the capital base to address the aspect of size and legal and regulatory framework review are important to ensure successful bank restructuring to record increased level of deposits. Commercial banks in Kenya have undertaken restructuring so as to be more competitive, to restore bank solvency and to mobilize more deposits. However, researchers on bank restructuring and bank deposits found conflicting results. The main objective of the study was to investigate the effect of bank restructuring on deposits of commercial banks in Kenya. The population of the study entailed all the 44 commercial banks licensed and registered under the banking act to do business in Kenya. Out of that data was availed from financial statements and annual reports of 39 commercial banks which were in operation for the period ranging from 2002 to 2014. Descriptive and inferential data analysis methods were used to analyze the secondary data collected. The empirical findings revealed that commercial banks use all the four types of bank restructuring which were financial, capital, operational and asset restructuring. It was further established that operational restructuring statistically affected bank deposits positively. Asset restructuring was found to have significant but negative influence on the deposits of commercial banks in Kenya. The research therefore, concludes that deposits can be mobilized through operational restructuring but can reduce significantly if there is asset restructuring. Deposits can therefore be increased through operational restructuring as an aspect of financial inclusion and financial deepening.
\end{abstract}

KEY WORDS: Bank restructuring, capital, financial, asset, operational, bank deposits.

\section{INTRODUCTION}

The financial sector in many economies is the main intermediary between savers who are interested in safe-keeping of their deposits and earning of interest income and borrowers who obtain loans at market rates of interest to finance profitable activities (Kwaning, et. al., 2014; Suehiro, 2002). Commercial banks which are the main financial intermediaries are in the business of accepting deposits, extending loans to their customers, discovering new financial products, underwriting, and servicing of investments made using their own resources (Fried, Lovell \& Eeckaut, 1993). Essentially they perform the role of agents for market participants who contract with them to obtain financial services with the main objective of increasing financial performance of banking institutions (Chang, et. al., 2014).

Deposits are money placed into banking institutions for safekeeping. The main types of deposits of banks are; savings deposits, current account deposits, term deposits, call deposits, money market accounts and certificate of deposits (Nilesh, 2013). Barako et. al., (2013) states that larger banks tend to have proportionately more branches both in the urban and in the rural areas than small banks implying that access to financial services can best be championed by larger banks. In Kenya, commercial banks are increasingly offering new services such as mobile banking, agency banking, bank-assurance, faceless banking and integrating microfinance in their banking system (CBK, 2018).

The account holder has the right to withdraw deposit funds, as set forth in the terms and conditions governing the account agreement. Banks tend to mobilize deposits so that they can use them as a basis for giving loans (Birchil \& Simmons, 2010). Funds mobilized by way of deposits may not be sufficient as a basis for extending loans to customers, therefore banks have to sometimes borrow so that they can in addition be able to meet their overhead expenses (Greuning \& Bratanovic, 2009). Banks mobilize deposits through Automated Teller Machine (ATM) services, agency banking, taking services to the people by opening branches close to their customers and suppliers and use of more relaxed modern banking halls (Dubel \& Berlin, 2013). 
Dziobek (1998) and Dziobek and Pazarbasioglu (1998) states that there are four main types of bank restructuring and they are; financial restructuring, operational restructuring, asset restructuring and capital restructuring. Financial restructuring focuses on the financial structure of the banking institution and is usually concerned about the liability and capital structures of banking institutions (Ernst \& Young, 2013). Operational restructuring focuses on reorganizing the activities of banks including their governance structure and also entails closing down or downsizing poorly performing entities or branches, downsizing and closing down product lines to reduce costs of bank operations (Espana, 2015). Asset restructuring entails reducing the poor performance in banks by increasing the liquidity of assets by holding more of current assets while ensuring that a large proportion is financial assets, and reducing the level of nonperforming loans through provisioning for problem loans and selling off bad loans (Mario, 2014).

Capital restructuring involves increasing the financial performance in banks by way of substitution of short-term debt and junior long-term debt with longer- term debt obligations (by converting debt to equity) to increase the financial structure of banks (Ernst \& Young, 2013). It sometimes involves direct capital injection by the shareholders and other times a bailout by government whereby additional capital is channeled into the banking entity by government (Dziobek and Pazarbasioglu, 1998; Osoro, 2014). Other types of bank restructuring identified by Bonish and MonteNegret (1998) and Franks and Sanzbar, (2002) are; market-based solutions, carving out bad assets, establishing an asset recovery agency, changing the guard, creating phoenixes, recapitalization, change of ownership structure, restructuring borrowers, institutional arrangements, counting the monetary and fiscal costs, appointment of interim management, operational reforms and legal, regulatory and policy review.

The institutional theory addresses issues relating to structures in institutions and emphasizes the fact that the processes by which social structures become established as authoritative guidelines for acceptable social behavior within organisations is an important aspect (Scott, 2004). Through restructuring organizations are enabled to change their form and structure so that they can be more efficient and can have a wider outreach (Hoenig \& Morris, 2012). Deposits are financial services and are the economic services provided by the financial industry, and are, a broad range of businesses that manage money, such as Credit Unions, commercial banks, credit-card companies, insurance companies, accountancy firms, consumer companies, stock brokerage firms, investment funds and certain government sponsored enterprises (Moore, 2003). This study restricts itself to deposits of commercial banks (Barako, Ross \& Brown, 2013).

Commercial banks in Kenya have undertaken restructuring to mitigate against bank failure, as an aspect of financial sector reform, as part of the government divestiture programme, to improve performance, to be more competitive, to improve bank solvency and to increase the banking sector capacity for financial intermediation. Commercial banks are expected to be profitable and efficient as they play their role of mobilizing deposits from savers and channeling funds to borrowers for them to survive in the long run. To improve efficiency commercial banks have embraced modernized banking halls, broad ATM network, state of art technology, widespread branch network and agency banking (Das \& Gosh, 2006). In Kenya, the practice has been that whenever a commercial bank experiences a crisis, the bank is placed under statutory management. This study finds out whether different types of bank restructuring could lead to different amounts of bank deposits. The current study established the relationships between bank restructuring and bank deposits of commercial banks in Kenya.

\section{CONCEPTUAL FRAMEWORK}

The knowledge gap highlighted lead to the development of the conceptual framework which guided the empirical research in filling the gaps identified from the review of literature. The conceptual model proposes that there is a relationship between bank restructuring and bank deposits. Based on the model, bank restructuring is the independent variable, which was measured using financial, capital, operational and asset restructuring; while bank deposits is the dependent variable which was measured using deposits to total assets ratio. Bank restructuring is expected to lead to an increase in bank deposits (Ithiri, 2013). The more the volume of transactions, the bigger the branch network, the more the ATMs, the more the bank agents and the better the technology, the easier it is to undertake the restructuring process and the more deposits that the commercial banks are expected to mobilize (AlObaidan, 2008; Barako, et. al., 2013). The expected relationship was that bank restructuring leads to increase in volume of bank deposits. 


\section{Bank Restructuring \\ - Financial Restructuring \\ - Capital Restructuring \\ - Operational Restructuring \\ - Asset Restructuring}

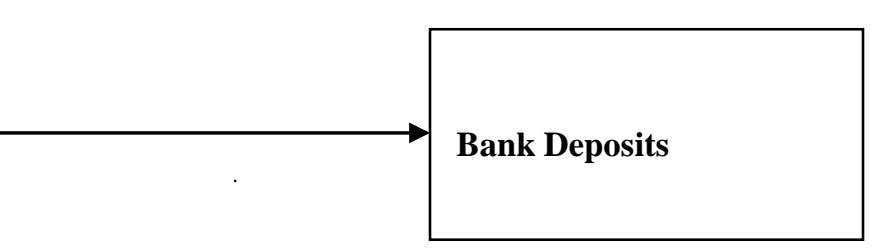

Figure 1: Conceptual Model

\section{RESEARCH HYPOTHESES}

The null hypothesis of the was:

$\mathbf{H}_{1}$ : The relationship between bank restructuring and bank deposits of commercial banks in Kenya is not significant.

\section{MATERIALS AND METHODS}

This study used secondary data for the period 2002 to 2014 . The thirteen-year study period for the 44 banks provides sufficient data to be used in the analysis. Data on the study variables was obtained from the financial statements. To achieve the objective of the study data was obtained from the financial statements of the commercial banks. Data on bank deposits was the deposits assets ratio. The data on bank restructuring focused on the four types of bank restructuring which are; financial, capital, operational and asset restructuring. Data was collected for the entire period of the study which was available from the financial statements for the institutions that were in business. Descriptive statistics were calculated in terms of mean, standard deviation, skewness and kurtosis. On the other hand, inferential analysis was based on regression model stated hereunder.

$\mathrm{BD}_{\mathrm{it}}=\dot{\alpha}+\beta_{1} \mathrm{FR}_{\mathrm{it}}+\beta_{2} \mathrm{CR}_{\mathrm{it}}+\beta_{3} \mathrm{OR}_{\mathrm{it}}+\beta_{4} \mathrm{AR}_{\mathrm{it}}+\varepsilon$
Where: BP is deposits assets ratio, FR is financial restructuring, $\mathrm{CR}$ is capital restructuring, $\mathrm{OR}$ is operational restructuring, $\mathrm{AR}$ is asset restructuring, $\alpha$ represented the constant term, $\beta_{1}, \beta_{2}$, $\beta_{3}$, and $\beta_{4}$ were the regression coefficients, it is the years under investigation while $\varepsilon$ is the error term.

\section{DESCRIPTIVE STATISTICS}

Measures of central tendency, dispersion and skewness including the mean, the standard deviation and kurtosis were estimated. The descriptive results shown in table 1 , indicate that the minimum value of deposits was 0.00 and the maximum value of the deposits was 0.98 . The mean value of deposits $67.56 \%$ of total assets and a standard deviation of $16.964 \%$ on average reveals that deposits are high with significant variation as indicated by the standard deviation value. The minimum deposits had a value of 0.00 and a maximum value of 0.98 denoting that deposit levels of banks varied with years. The statistics on skewness and kurtosis is a revelation that the data is normally distributed. At $95 \%$ confidence interval the mean of the deposits had no bias. In the same token, the level of bias was zero for the standard deviation, skewness and kurtosis at the $95 \%$ confidence level. 
Table 1: Bank Restructuring and Deposits

\begin{tabular}{|c|c|c|c|c|c|c|c|c|c|c|c|}
\hline & \multirow{2}{*}{$\begin{array}{c}\text { N } \\
\text { Statistic }\end{array}$} & \multirow{2}{*}{$\begin{array}{c}\text { Minimum } \\
\text { Statistic }\end{array}$} & \multirow{2}{*}{$\begin{array}{c}\text { Maximum } \\
\text { Statistic }\end{array}$} & \multirow{2}{*}{$\begin{array}{c}\text { Mean } \\
\text { Statistic }\end{array}$} & \multirow{2}{*}{$\begin{array}{c}\begin{array}{c}\text { Std. } \\
\text { Deviation }\end{array} \\
\text { Statistic }\end{array}$} & \multicolumn{3}{|c|}{ Skewness } & \multicolumn{3}{|c|}{ Kurtosis } \\
\hline & & & & & & Statistic & \begin{tabular}{|c|} 
Std. \\
Error
\end{tabular} & \begin{tabular}{|c|} 
Z - \\
Value
\end{tabular} & Statistic & \begin{tabular}{|l} 
Std. \\
Error
\end{tabular} & \begin{tabular}{|c|} 
Z - \\
Value
\end{tabular} \\
\hline Deposits & 507 & 0.00 & 0.98 & 0.6756 & 0.16964 & -1.963 & 0.108 & -0.055 & 4.722 & 0.217 & 0.046 \\
\hline $\begin{array}{c}\text { Financial } \\
\text { restructuring }\end{array}$ & 507 & .00 & .94 & .0622 & .15726 & 3.855 & .108 & 0.028 & 14.929 & .217 & 0.015 \\
\hline $\begin{array}{c}\text { Capital } \\
\text { restructuring } \\
\end{array}$ & 507 & .00 & .46 & .1393 & .07365 & .787 & .108 & 0.137 & 1.794 & .217 & 0.121 \\
\hline $\begin{array}{c}\text { Operational } \\
\text { restructuring }\end{array}$ & 507 & .00 & .40 & .0510 & .04151 & 3.567 & .108 & 0.030 & 19.884 & .217 & 0.011 \\
\hline $\begin{array}{c}\text { Asset } \\
\text { restructuring }\end{array}$ & 507 & .00 & .84 & .0845 & .11099 & 3.181 & .108 & 0.034 & 13.020 & .217 & 0.017 \\
\hline
\end{tabular}

\section{Source: Research Findings}

Bank restructuring was denoted by financial restructuring, capital restructuring, operational restructuring and asset restructuring variables. Financial restructuring had a debt to total asset ratio of $6.22 \%$ with a variation of $15.726 \%$ on either side. Capital restructuring had an equity to asset ratio of $13.93 \%$ with a standard deviation of $7.365 \%$. Operational restructuring indicated a change in the aggregate of branch and ATM ratio of less than one aggregate unit and branches and ATMs in aggregate with a standard deviation of less than one branch and/or ATM. Asset restructuring showed a nonperforming loan to total loan ratio of 0.0845 meaning that on average nonperforming loans to total loans is on average $8.45 \%$. This means that for all loans extended to the customers, $8.45 \%$ ends up being nonperforming loans. The standard deviation on nonperforming loans to total loans is $11.09 \%$.

Additionally, financial restructuring, capital restructuring, operational restructuring and asset restructuring had positive skewness while all the variables had positive kurtosis. The skewness $\mathrm{z}-$ values show that all the data observations are skewed to the right. The kurtosis $z$-value for financial restructuring, capital restructuring, operational restructuring and asset restructuring are within the acceptable range of less than +1.96 and more than 1.96. The conclusion is therefore that the data on the independent variables follow a normal distribution.

The minimum value for financial restructuring is 0.00 while the maximum value is 0.94 , an indication that commercial banks have different levels of debt in their financial structure. The extent of usage of debt varies across and among banks as indicated by the level of the standard deviation. At $95 \%$ confidence interval, the mean is significant with no level of bias. The standard deviation is also significant at $95 \%$ confidence level and the data on financial restructuring as measured using the level of bank borrowing is normally distributed. Capital restructuring is an important variable because banks generally restructure their capital either by way of requiring investors to inject additional capital or by way of receiving additional capital from government especially the government owned commercial banks. The minimum value for this variable is 0.00 while the maximum value is 0.46 an indication that the extent to which, banks restructure their capital varies.

Operational restructuring focuses on the ability and extent to which banks restructure their operations. Although the costs of restructuring commercial banks is usually significant and might lead to reduced profits in the short run, expanded branch network, increasing the number of ATMs, entrenchment of agency banking in the banking sector calls for operational restructuring. The test of normality estimates a skewness $\mathrm{z}$-value of 0.030 while the kurtosis measure is 0.011 . The skewness $z$ - measure of operational restructuring suggests that data is skewed to the right. The kurtosis $\mathrm{z}-$ measure of operational restructuring is below 1.96 and above 1.96, an indication that the data is normally distributed. Young and Rice (2003) states that wellmanaged banks expand more slowly into noninterest activities such as opening subsidiaries and branches that might not necessarily generate interest income to diversify their profits.

The valid observations of asset restructuring as denoted by the N-statistic is in line with the fact that commercial banks generally tend to restructure their assets by providing for the nonperforming loans. The mean of the observations is 0.0845 while the standard deviation is 0.11099 . This is an indication that the level of non-performing loans of commercial banks in Kenya varies significantly. The skewness zmeasure of asset restructuring is 0.034 and the kurtosis z- measure is 0.017 indicating that the data is normally distributed. The minimum value is 0.00 while the maximum value is 0.84 . This is an indication that the difference between the lowest and the highest amounts of nonperforming loans of commercial banks in Kenya is significant. At 95\% confidence interval, the mean is not significant at 0.0845 but the standard deviation is significant at 0.11099 with no level of bias. The data on asset restructuring as measured using the level of bank nonperforming loans is normally distributed. 
Suehiro (2002) in his research on restructuring and re-engineering of local commercial banks in Thailand finds that NPLs decreased from $42.9 \%$ to $10.5 \%$ during the study period 1998 to 2001 . The introduction of Credit Reference Bureau regulations that were operationalized in 2009 enabled the sharing of credit information to facilitate the pricing of credit risk, accumulation of information capital and increased access to credit. It is expected that the credit information sharing system enhances the decision making process of credit providers in Kenya as they seek to mitigate risks associated with information asymmetry.

\section{REGRESSION ANALYSIS}

This section focuses on bank deposits and the study variables of bank restructuring that influence bank deposits. This research study sought to determine whether the independent variables (financial restructuring, capital restructuring, operational restructuring and asset restructuring), have an influence on the dependent variable (bank deposits) of commercial banks in Kenya. This led to test of the following research hypothesis:

\section{H1: The relationship between bank} restructuring and bank deposits of commercial banks in Kenya is not significant.

This was done based on the analytical equation given below:

$$
\mathrm{BD}_{\mathrm{it}}=\alpha+\beta_{1} \mathrm{FR}_{\mathrm{it}}+\beta_{2} \mathrm{CR}_{\mathrm{it}}+\beta_{3} \mathrm{OR}_{\mathrm{it}}+\beta_{4} \mathrm{AR}_{\mathrm{it}}+\varepsilon
$$

The model produced a coefficient of determination $R^{2}$ which was used in this study was a useful tool because it gives the proportion of the fluctuation (variation) of one variable that is predictable from the other variable. This measure allowed the study to determine how certain variables can be used in making predictions from a certain model used in this investigation. The coefficient of determination is the ratio of the explained variation to the total variation. The coefficient of determination is such that $0 \leq \mathrm{r}^{2} \leq 1$, and denotes the strength of the linear association between $X$ and $Y$. The higher the value of $\mathrm{R}^{2}$ the higher the explanatory power of the regression model. In interpreting the results of multiple regression analysis, the $R$ squared was used to estimate how well the model fitted the data (Anderson \& Darling, 1954).

Table 5, indicate that $R^{2}=0.096$ and this shows that all the bank restructuring variables used in this model has ability of explaining $9.6 \%$ of the bank deposits. With an $F$ statistic of 13.311 and $p$-value of 0.000 , it can be construed that the research should reject the null hypothesis that the relationship between bank restructuring and bank deposits of commercial banks in Kenya is not significant since the error we make by doing so is $<0.05$. The results on coefficients show that there exists a significant positive relationship between the operational restructuring and bank deposits. This is reflected by the positive regression coefficient of 0.607 ( $t-$ value of 3.401) and a $p$-value of 0.001 . This means that operational restructuring contributes $60.7 \%$ of bank deposits. Asset restructuring has a significant but negative effect on deposits as indicated by the coefficient of $-0.419(\mathrm{t}=6.084)$ and a $p$-value of 0.000 . Likewise, this could mean that an increase in the ratio of asset restructuring could reduce bank deposits by $41.9 \%$.

Financial restructuring was found not to be significant in influencing deposits of banks as denoted by the coefficient of $-0.046(t=0.997)$ and a $p$ - value of 0.319 . The findings reveal that capital restructuring within commercial banks affects bank deposits insignificantly given a coefficient value of $0.152(\mathrm{t}=1.457)$ and a $p$-value of 0.146 . The implication is that when the deposits of a particular bank decrease, banks should utilize their existing assets properly while addressing weaknesses in their operations such as branches and ATMs to boost the deposit level. 
Table 2: The Effects of Bank Restructuring on Bank Deposits

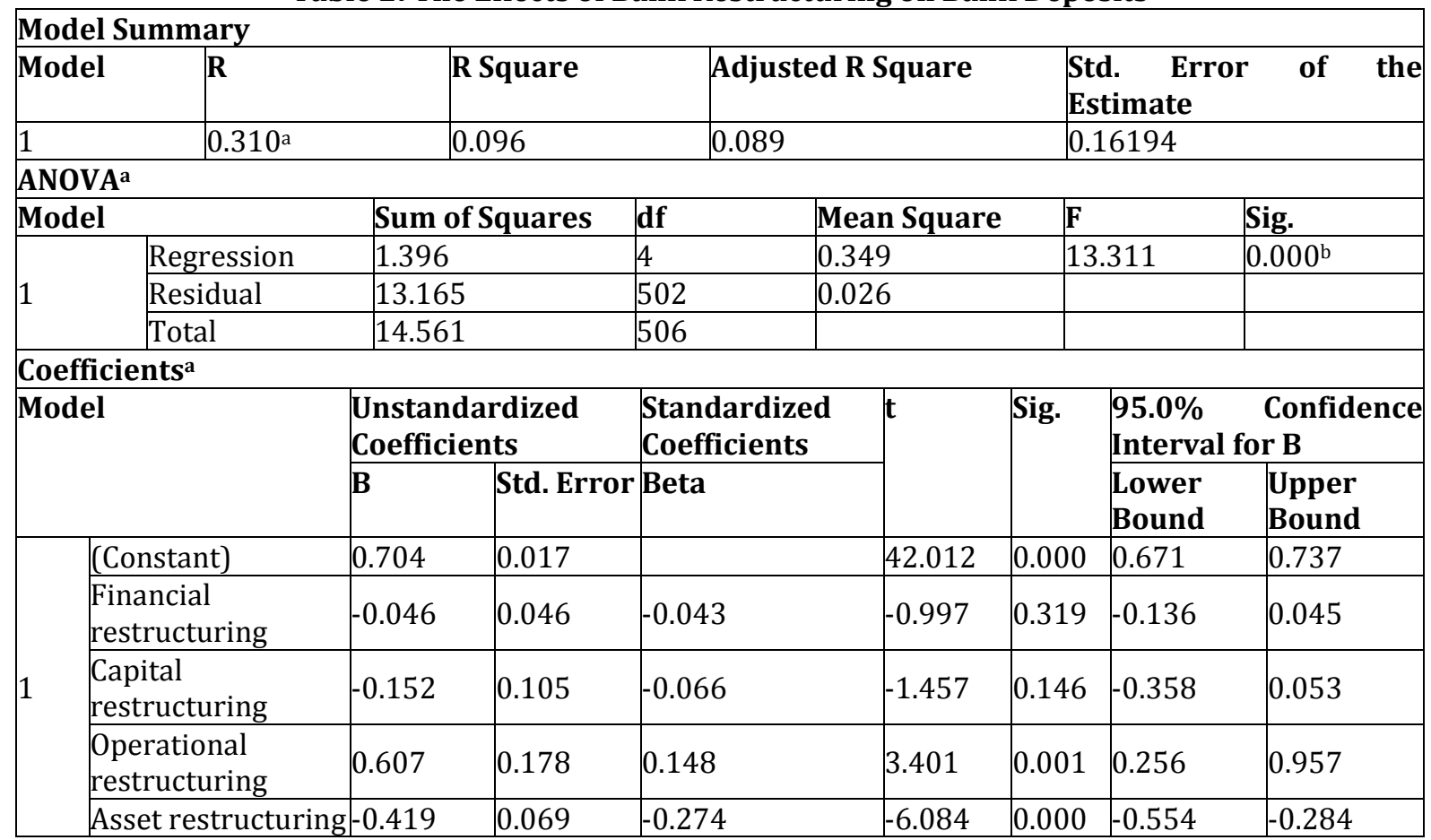

a. Dependent Variable: Deposits

Source: Research Findings

After taking into account the significance of the variables in the model as indicated by the $\mathrm{p}-$ values, the resulting model of deposits is as follows:

$\mathrm{BD}=0.704+0.607 \mathrm{OR}-0.419 \mathrm{AR}$

This means that it is only operational restructuring and asset restructuring that significantly influence the level of deposits of commercial banks in Kenya. Whereas operational restructuring increases bank deposits, asset restructuring was found to significantly reduce bank deposits. Proper management of bank operations and asset quality are important if the objective is to increase bank deposits. All the independent variables were used to establish the influence of deposits because of the importance of branches, ATMs, and other operating activities in influencing operational restructuring and its associated costs. When many customers are able to access banks through the many branches which promise a wide geographical coverage, and ATMs and other innovations such as agency banking the customers are expected to influence the deposit levels.

The more the branches, the more the deposits a bank is likely to mobilize. Ignoring operational restructuring although not found to be significant in the first objective would be quite misleading due to the importance of operational restructuring in mobilizing deposits. This concurs with the findings of Beck, Demirguc and Peria (2007) who found out that a wide branch network, opening of bank subsidiaries, agency banking and installation of an
ATM network are important in enabling access to financial services and mobilizing deposits of commercial banks. The findings of this study also concur with that of Suehiro (2002) providing for nonperforming loans is a sign of poor asset quality and may keep away depositors who might favour dealing with banks which provide less on their loans.

\section{CONCLUSIONS}

The study had the objective of investigating the relationship between bank restructuring and deposits of commercial banks in Kenya. The two categories of the study variables used to achieve the objectives of the study were; independent (bank restructuring) and the dependent variable (deposits). Bank restructuring which was the independent variable had four attributes which were financial restructuring, capital restructuring, operational restructuring and asset restructuring. The study concludes that commercial banks undertake all types of bank restructuring under study, that is financial restructuring, capital restructuring, operational restructuring and asset restructuring. It was therefore established that operational restructuring was found to have a significant positive effect on bank deposits while asset restructuring was found to have a significant negative effect on bank deposits. Financial restructuring and capital restructuring were not found to have a significant effect on bank deposits. 
The study concludes that bank restructuring affects bank deposits of commercial banks in Kenya. If the objective of banks is to increase bank deposits banks need to restructure their operations more but need to keep their asset quality in check. This is because operational restructuring tends to be associated with increasing the branch networks, increasing the number of ATMs, incorporating agency banking, entrenching internet banking, mobile banking, faceless banking, RTGS and other aspects of financial innovations encompassing, product, process and institutional innovations which all lead to access to financial services thus increasing the deposit levels. Asset restructuring on the other had has the main intention of increasing the asset quality as measured using the nonperforming loan ratio. Reducing the nonperforming loans in the loan book tend to be associated with huge provisioning of non-performing loans which is an expense and therefore reduces bank profits significantly.

Low profits banks as a result of high nonperforming loans tend to discourage depositors from keeping money in banks as they look for alternative investment vehicles. This explains the negative effect of asset restructuring on bank deposits of commercial banks in Kenya. Essentially, although operational restructuring had the highest effect on deposits of commercial banks, the effect of bank restructuring on the level of financial inclusion and financial deepening is important which might be a wakeup call for banks to embark on operational restructuring which would improve financial deepening and increase the level of financial inclusion.

\section{REFERENCES}

1. Al-Obaidan, A. M. (2008). Market structure concentration and performance in the commercial banking industry of emerging markets; European Journal of Economics, Finance and Administrative Sciences, 12: $104-$ 115

2. Beck, T, Demirguc-Kunt, A. \& Peria M. (2007). Reaching out: Access to use of banking services across countries. Journal of Financial Economics. 85: $234-266$

3. Birchil, J. \& Simmons, R. (2010). The cooperative reform process in Tanzania and Sri Lanka. Annals of Public and Co-operative Economics. 81(3), 467 - 500.

4. Bonish, M. \& Montes-Negret R. (1998). Restructuring distressed banks in transition economies: Lessons from Central Europe and Ukraine, The World Bank, Washington.

5. Central Bank of Kenya (2018). Central Bank of Kenya Bank Supervision Report

6. Das, A. \& Ghosh, S. (2006). Financial deregulation and efficiency: An empirical analysis of Indian banks during the post reform period. Review of Financial Economics 15, 193 221.
7. De Young, R. \& Rice, T. (2003), Noninterest income and financial performance at U.S. commercial banks; Supervision and Regulation Department: Federal Reserve Bank of Chicago.

8. Demirguc-Kunt, A. \& Huzinga, H. (2000), Financial structure and bank profitability, World Bank, Research Paper, Washington D.C.

9. Dubel, H. J. \& Berlin, F. (2013). The Capital structure of banks and practice of bank restructuring; Eight case studies on current bank restructuring in Europe; Center for Financial Studies; University of Frankfurt.

10. Dziobek, C. \& Pazarbsioglu, C. (1998). Lessons from systemic bank restructuring; Economic Issues NO. 14, IMF.

11. Dziobek, C. (1998). Market-based policy instruments for systemic bank restructuring, IMF Working Paper, 98/113, IMF, Washington D.C.

12. Ernst \& Young (2013). The World of bank restructuring; to restructure or not to restructure? Africa Advisory Services Journal, 5: $119-213$

13. Espana, B. (2015). Public financial assistance in the restructuring of the Spanish banking sector. Journal of Financial Economics. 17, 211 - 256

14. Franks, J. \& Sanzbar, S. (2002). Equity issues by distressed firms. London Business School.

15. Fried, H. O., Lovell, C. A. K. \& Eeckaut, P. V. (1993). Evaluating the performance of U.S. credit unions. Journal of Banking and Finance. 17(5), $251-265$.

16. Greuning, H.V. \& Bratanovic, S.B. (2009). Analyzing Banking Risk: A framework for assessing corporate governance and risk management. 3rd edition. The International Bank for Reconstruction and Development; The world Bank, Washington D.C.

17. Hoenig, T. M. \& Morris, C. S. (2012). Restructuring the banking system to improve safety and soundness, Federal Deposit Insurance Corporation and Federal Reserve Bank of Kansas City.

18. Ithiri, M. D. (2013). Corporate restructuring and its effects on Kenya Commercial Bank performance. A Research Project in Masters of Business Administration, School of Business, Kenyatta University.

19. Kwaning, C. O., Churchill, R. Q. \& Opuku, A. K. (2014). The impact of organisational restructuring on the financial performance of public banks; A post restructuring assessment of Agricultural Development Bank, Ghana. Journal of Financial Accounting, 5, $106-112$

20. Mario, D. (2014). Bank restructuring and the economic recovery; The European Central Bank Euro-system; Speech by the President of the ECB at the Presentation Ceremony of the Schumpeter Award, Oesterreichische National Bank, Vienna, March. Accessed from http://www.ecb.europa.eu.

21. Moore, D. (2003). Survey of financial literacy in Washington State. Knowledge, behaviour, attitudes and experiences. Technical report, Social Economic Sciences Research Center. Washington State University. 
22. Nor, F. M., Alias, N. \& Yaacob, M. H. (2009). Corporate restructuring, firm characteristics and performance, Jurnal Pengurusan, 27, 129 - 141

23. Osoro, P. M. (2014). The effect of financial restructuring on the financial performance of commercial banks in Kenya. Doctoral dissertation, University of Nairobi.

24. Scott, W. R. (2004). Institutional theory in encyclopaedia of social theory, George Ritzer, ed. Thousand Oaks, CA: Sage. $408-414$

25. Suehiro, A. (2002). Restructuring and reengineering of local commercial Banks in Thailand, Institute of Social Science, and University of Tokyo. 